\title{
Efficacy of Ceritinib After Alectinib for ALK-positive Non-small Cell Lung Cancer
}

\author{
HIRONORI YOSHIDA, YOUNG HAK KIM, HIROAKI OZASA, YUICHI SAKAMORI, TAKAHIRO TSUJI, \\ TAKASHI NOMIZO, YUTO YASUDA, TOMOKO YAMAMOTO, HITOMI AJIMIZU and TOYOHIRO HIRAI \\ Department of Respiratory Medicine, Graduate School of Medicine, Kyoto University, Kyoto, Japan
}

\begin{abstract}
Background: Alectinib is a new standard treatment for treatment-naïve anaplastic lymphoma kinase (ALK)-positive non-small cell lung cancer (NSCLC); however, resistance ultimately develops in almost all patients, and data regarding the efficiency of ceritinib for such patients are insufficient. Patients and Methods: Patients with ALK-positive NSCLC treated at the Kyoto University Hospital from January 2012 to March 2017 were reviewed. Patients who were treated with ceritinib after alectinib were identified, and the efficacy of ceritinib after alectinib was retrospectively evaluated. Results: There were 35 patients with ALK-positive NSCLC, nine of whom received ceritinib after alectinib. The overall response rate to ceritinib was $44 \%$. It was $16 \%$ in patients who received ceritinib immediately after alectinib, and $100 \%$ in patients who received chemotherapy before ceritinib. The median progression-free survival for patients treated with ceritinib was 4.4 months $(95 \%$ confidence interval $(C I)=1.1-6.5$ months). Conclusion: Ceritinib demonstrated a modest clinical benefit after failure of alectinib. Ceritinib may be a reasonable treatment option in this setting.
\end{abstract}

Anaplastic lymphoma kinase $(A L K)$ rearrangement is an established driver oncogene in non-small cell lung cancer (NSCLC) (1), and ALK inhibitors are the standard treatment for ALK-positive NSCLC. Crizotinib is a first-generation ALK inhibitor $(2,3)$, and current second-generation ALK

This article is freely accessible online.

Correspondence to: Young Hak Kim, MD, Ph.D., Department of Respiratory Medicine, Graduate School of Medicine, Kyoto University, 54 Shogoin-Kawaharacho, Sakyo-ku, Kyoto 606-8507, Japan. Tel: +81 757513830, Fax: +81 757514643, e-mail: ekim@kuhp.kyoto-u.ac.jp

Key Words: Non-small cell lung cancer, ALK-positive, alectinib, ceritinib. inhibitors, such as alectinib and ceritinib, are also available in Japan. Previous studies have demonstrated the efficacy of alectinib in patients with crizotinib-resistant (4-6) or crizotinib-naïve ALK-positive NSCLC (7). Furthermore, two randomized phase III studies independently found that alectinib was significantly superior to crizotinib in progression-free survival (PFS), response rate, and toxicity $(8,9)$. Based on the results of the phase III studies, alectinib is considered to be a new standard treatment for treatmentnaïve ALK-positive NSCLC; however, almost all patients acquire resistance to alectinib, leaving only two treatment options: cytotoxic chemotherapy and another secondgeneration ALK inhibitor, ceritinib. Preclinical data have suggested the efficacy of ceritinib after alectinib (10), but clinical data are limited. Here, we investigated the clinical efficacy of ceritinib after failure of alectinib for ALKpositive NSCLC.

\section{Patients and Methods}

Patients with ALK-positive NSCLC treated at the Kyoto University Hospital from January 2012 to March 2017 were reviewed. Patients who were treated with ceritinib after alectinib were identified, and the efficacy of ceritinib after alectinib was retrospectively evaluated. Patients were diagnosed as having ALKpositive NSCLC when the tumor sample was double-positive by both immunohistochemistry and fluorescence in situ hybridization. The objective tumor response was evaluated according to the Response Evaluation Criteria for Solid Tumors, version 1.1 (11). PFS was measured from the date of initiation of ceritinib to the date of disease progression or death. All analyses were performed with JMP 10 software (SAS Institute, Cary, NC, USA). The cutoff date for data collection was December 28, 2017. This study was approved by the Institutional Review Board (approval number \#G0799).

\section{Results}

Patient characteristics. There were 35 patients with ALKpositive NSCLC, nine of whom received ceritinib after alectinib. The clinical characteristics of the nine patients are 
Table I. Summary of the characteristics of the nine patients who received ceritinib (CER) after alectinib (ALC).

\begin{tabular}{|c|c|c|c|c|c|c|c|c|c|c|c|c|c|}
\hline \multirow[b]{2}{*}{ Case } & \multirow[b]{2}{*}{$\begin{array}{l}\text { Age } \\
\text { (years) }\end{array}$} & \multirow[b]{2}{*}{ Gender } & \multirow[b]{2}{*}{ PS } & \multirow[b]{2}{*}{ Histology } & \multirow[b]{2}{*}{$\begin{array}{l}\text { Treatment } \\
\text { sequence }\end{array}$} & \multicolumn{4}{|c|}{ ALC treatment } & \multicolumn{4}{|c|}{ CER treatment } \\
\hline & & & & & & Response & $\begin{array}{c}\text { Duration } \\
\text { of } \\
\text { therapy } \\
\text { (months) }\end{array}$ & $\begin{array}{c}\text { Reason } \\
\text { for } \\
\text { disconti- } \\
\text { nuation }\end{array}$ & $\begin{array}{c}\text { Interval } \\
\text { between } \\
\text { ALC and } \\
\text { CER (days) }\end{array}$ & $\begin{array}{c}\text { Initial } \\
\text { dose } \\
\text { (mg/day) }\end{array}$ & $\begin{array}{c}\text { Dose } \\
\text { reduction }\end{array}$ & Response & $\begin{array}{c}\text { Response } \\
\text { duration } \\
\text { (months) }\end{array}$ \\
\hline 1 & 33 & M & 1 & $\mathrm{Ad}$ & $\begin{array}{c}\mathrm{Cis} / \mathrm{PEM} \rightarrow \\
\mathrm{Cb} / \mathrm{PAC} / \mathrm{BEV} \rightarrow \\
\mathrm{NIVO} \rightarrow \\
\mathrm{ALC} \rightarrow \mathrm{CER}\end{array}$ & $\mathrm{PD}$ & 6.6 & $\mathrm{PD}$ & 7 & 750 & Yes & PD & 1.5 \\
\hline 2 & 93 & $\mathrm{~F}$ & 2 & Ad & ALC $\rightarrow$ CER & PR & 8.0 & PD & 1 & 150 & No & PR & $2.7 *$ \\
\hline 3 & 27 & $\mathrm{~F}$ & 1 & $\mathrm{Ad}$ & $\begin{array}{c}\mathrm{ALC} \rightarrow \\
\mathrm{Cb} / \mathrm{PEM} / \mathrm{BEV} \\
\rightarrow \mathrm{CER}\end{array}$ & PR & 8.4 & PD & 344 & 750 & No & PR & 4.4 \\
\hline 4 & 66 & F & 2 & LCNEC & ALC $\rightarrow$ CER & PR & 22.8 & $\mathrm{PD}$ & 1 & 450 & No & $\mathrm{PD}$ & 2.8 \\
\hline 5 & 57 & $\mathrm{~F}$ & 0 & Ad & $\begin{array}{c}\mathrm{Cb} / \mathrm{PAC} / \mathrm{BEV} \rightarrow \\
\mathrm{ERL} / \mathrm{BEV} \rightarrow \\
\mathrm{PEM} \rightarrow \mathrm{DOC} \rightarrow \\
\mathrm{CPT} \rightarrow \mathrm{CRZ} \rightarrow \\
\mathrm{ALC} \rightarrow \mathrm{GEM} \rightarrow \\
\mathrm{S}-1 / \mathrm{BEV} \rightarrow \mathrm{CER}\end{array}$ & PR & 6.5 & ILD & 441 & 750 & Yes & PR & $4.0^{*}$ \\
\hline 6 & 44 & M & 0 & $\mathrm{Ad}$ & $\begin{array}{c}\mathrm{Cb} / \mathrm{PEM} / \mathrm{BEV} \rightarrow \\
\mathrm{CRZ} \rightarrow \mathrm{DOC} \rightarrow \\
\mathrm{ALC} \rightarrow \mathrm{CER}\end{array}$ & PR & 29.9 & PD & 1 & 750 & Yes & $\mathrm{SD}$ & 6.5 \\
\hline 7 & 70 & $\mathrm{~F}$ & 1 & $\mathrm{Ad}$ & $\begin{array}{c}\mathrm{Cb} / \mathrm{PAC} / \mathrm{BEV} \rightarrow \\
\mathrm{PEM} \rightarrow \mathrm{S}-1 \rightarrow \\
\mathrm{GEM} \rightarrow \mathrm{CPT} \rightarrow \\
\mathrm{DOC} \rightarrow \mathrm{ALC} \rightarrow \\
\mathrm{CER}\end{array}$ & PR & 10.5 & PD & 7 & 750 & Yes & PD & 1.1 \\
\hline 8 & 65 & M & 1 & $\mathrm{Ad}$ & $\begin{array}{c}\mathrm{Cb} / \mathrm{PEM} / \mathrm{BEV} \rightarrow \\
\mathrm{CRZ} \rightarrow \mathrm{ALC} \rightarrow \\
\mathrm{Cb} / \mathrm{PAC} / \mathrm{BEV} \rightarrow \\
\mathrm{NIVO} \rightarrow \mathrm{DOC} \rightarrow \\
\mathrm{CER}\end{array}$ & PR & 12.8 & $\mathrm{PD}$ & 287 & 600 & No & PR & 3.5 \\
\hline 9 & 41 & M & 2 & $\mathrm{Ad}$ & $\begin{array}{c}\mathrm{CRZ} \rightarrow \mathrm{ALC} \rightarrow \\
\mathrm{CER}\end{array}$ & PR & 24.5 & $\mathrm{PD}$ & 1 & 750 & Yes & SD & $5.8^{*}$ \\
\hline
\end{tabular}

M, Male; F, female; PS, Eastern Cooperative Oncology Group Performance Status; Ad, adenocarcinoma; LCNEC, large-cell neuroendocrine carcionoma; CRZ, crizotinib; Cis, cisplatin; PEM, pemetrexed; Cb, carboplatin; PAC, paclitaxel, BEV, bevacizumab; NIVO, nivolumab; ERL, erlotinib; DOC, docetaxel; CPT, irinotecan; GEM, gemcitabine; S-1, tegafur/gimeracil/oteracil; PR, partial response; SD, stable disease; PD, progressive disease; ILD, interstitial lung disease. *Censored.

summarized in Table I. The median age at the time of ceritinib initiation was 57 (range $=27-93$ ) years. Four patients were male, and three patients had an Eastern Cooperative Oncology Group Performance Status of 2. All but one patient with large-cell neuroendocrine carcinoma demonstrated adenocarcinoma histology. Four patients received both crizotinib and alectinib before ceritinib, and six patients received ceritinib immediately after failure of alectinib. Eight patients had achieved partial response with alectinib, and the median duration of alectinib treatment was 10.5 (range $=6.5$ 29.9) months. The reasons for alectinib termination were progressive disease in eight patients and toxicity (interstitial lung disease) in one.
Efficacy of ceritinib after alectinib for ALK-positive NSCLC. Ceritinib treatment and its efficacy is summarized in Table I. The starting dose of ceritinib was $750 \mathrm{mg}$ in six patients, five of whom required dose reduction. Of the nine patients, four had a partial response, two had stable disease, and three had progressive disease. The overall response rate (ORR) and disease control rate were $44 \%$ and $67 \%$, respectively. The ORR was $16 \%$ in six patients who received ceritinib immediately after alectinib, and $100 \%$ in three patients who received chemotherapy before ceritinib. The median PFS was 4.4 months (95\% confidence interval=1.1-6.5 months) (Figure 1). At the time of data cut-off, three patients were still receiving ceritinib (median duration of follow-up was 8.5 months). 


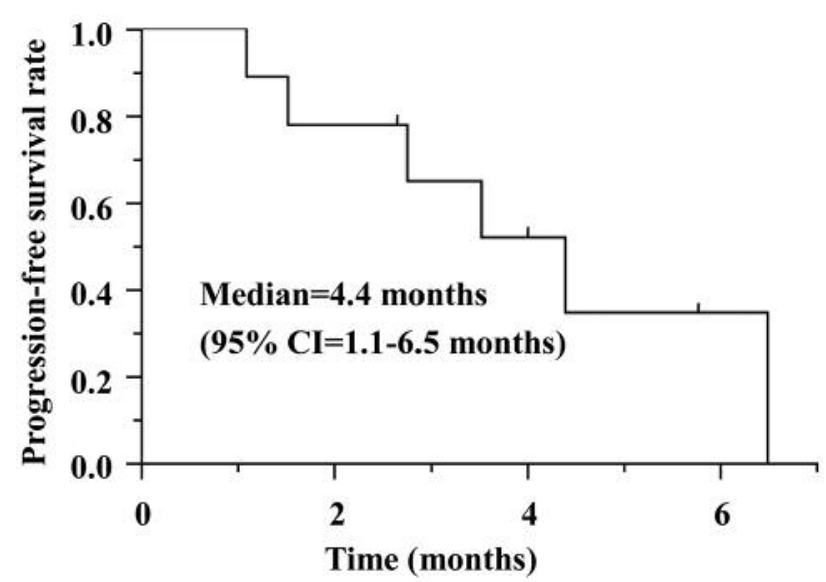

Figure 1. Kaplan-Meier curve for progression-free survival. CI: Confidence interval.

\section{Discussion}

Currently, ceritinib is a second-line treatment option for patients with ALK-positive NSCLC; however, little is known about the efficacy of ceritinib in patients who were previously treated with alectinib. In the current study, ceritinib demonstrated a modest clinical benefit in this setting, with an ORR and median PFS of $44 \%$ and 4.4 months, respectively.

To date, only one prospective study has evaluated the efficacy of ceritinib after alectinib in patients with ALKpositive NSCLC. The ASCEND-9 study recruited 20 patients with ALK-positive NSCLC who were previously treated with alectinib, and reported an ORR of $25 \%$ and median PFS of 3.7 months (12). The efficacy of ceritinib observed in ASCEND-9 was consistent with our results, except that four out of five responders in the ASCEND-9 study received ceritinib immediately after alectinib, whereas in our study it was only one out of four. This suggests that it is difficult to predict the efficacy of ceritinib after alectinib based on clinical characteristics.

Thus far, several mechanisms of acquired resistance to ALK inhibitors have been identified, including secondary $A L K$ mutations, $A L K$ gene copy-number increase, and activation of bypass signaling pathways (13-16). Among them, secondary $A L K$ mutations are dominant mechanisms in patients treated with second-generation ALK inhibitors such as alectinib $(17,18)$. Moreover, an in vitro study found that each secondary $A L K$ mutation has a different sensitivity to different ALK inhibitors (10). Katayama et al. first identified the $A L K$ I1171T secondary mutation in a patient who developed resistance to alectinib. They demonstrated that the I1171T mutation confers resistance to alectinib but remains sensitive to ceritinib, using a cell line derived from the patient who subsequently responded to ceritinib (19). In contrast, ceritinib is ineffective against the ALKG1202R secondary mutation, which is sensitive to third-generation ALK inhibitors $(10,18)$. These results strongly suggest that examining resistance mechanisms, especially resistanceassociated mutations, is essential for selecting drugs for patients with ALK-positive NSCLC resistant to alectinib.

In conclusion, we evaluated the efficacy of ceritinib after alectinib in nine patients with ALK-positive NSCLC. Ceritinib demonstrated a modest clinical benefit after failure of alectinib. Although the sample size was small and it was a retrospective study, our results suggest that ceritinib may be a reasonable treatment option in this setting.

\section{Conflicts of Interest}

The Authors declare no conflicts of interest.

\section{References}

1 Soda M, Choi YL, Enomoto M, Takada S, Yamashita Y, Ishikawa $S$, Fujiwara $S$, Watanabe $H$, Kurashina $K$, Hatanaka $H$, Bando M, Ohno S, Ishikawa Y, Aburatani H, Niki T, Sohara Y, Sugiyama $\mathrm{Y}$ and Mano $\mathrm{H}$ : Identification of the transforming $E M L 4-A L K$ fusion gene in non-small-cell lung cancer. Nature 448: 561-566, 2007.

2 Shaw AT, Kim DW, Nakagawa K, Seto T, Crinó L, Ahn MJ, De Pas T, Besse B, Solomon BJ, Blackhall F, Wu YL, Thomas M, O'Byrne KJ, Moro-Sibilot D, Camidge DR, Mok T, Hirsh V, Riely GJ, Iyer S, Tassell V, Polli A, Wilner KD and Jänne PA: Crizotinib versus chemotherapy in advanced ALK-positive lung cancer. N Engl J Med 368: 2385-2394, 2013.

3 Solomon BJ, Cappuzzo F, Felip E, Blackhall FH, Costa DB, Kim DW, Nakagawa K, Wu YL, Mekhail T, Paolini J, Tursi J, Usari T, Wilner KD, Selaru P and Mok TS: Intracranial efficacy of crizotinib versus chemotherapy in patients with advanced ALK-positive non-small-cell lung cancer: Results From PROFILE 1014. J Clin Oncol 34: 2858-2865, 2016.

4 Shaw AT, Gandhi L, Gadgeel S, Riely GJ, Cetnar J, West H, Camidge DR, Socinski MA, Chiappori A, Mekhail T, Chao BH, Borghaei H, Gold KA, Zeaiter A, Bordogna W, Balas B, Puig O, Henschel V, Ou SI and Study Investigators: Alectinib in ALKpositive, crizotinib-resistant, non-small-cell lung cancer: A singlegroup, multicentre, phase 2 trial. Lancet Oncol 17: 234-242, 2016.

5 Gadgeel SM, Gandhi L, Riely GJ, Chiappori AA, West HL, Azada MC, Morcos PN, Lee RM, Garcia L, Yu L, Boisserie F, Di Laurenzio L, Golding S, Sato J, Yokoyama S, Tanaka T and Ou SH: Safety and activity of alectinib against systemic disease and brain metastases in patients with crizotinib-resistant $A L K$ rearranged non-small-cell lung cancer (AF-002JG): Results from the dose-finding portion of a phase 1/2 study. Lancet Oncol 15: 1119-1128, 2014.

6 Ou SH, Ahn JS, De Petris L, Govindan R, Yang JC, Hughes B, Lena H, Moro-Sibilot D, Bearz A, Ramirez SV, Mekhail T, Spira A, Bordogna W, Balas B, Morcos PN, Monnet A, Zeaiter A and Kim DW: Alectinib in crizotinib-refractory $A L K$-rearranged nonsmall-cell lung cancer: A phase II global study. J Clin Oncol 34: 661-668, 2016. 
7 Seto T, Kiura K, Nishio M, Nakagawa K, Maemondo M, Inoue A, Hida T, Yamamoto N, Yoshioka H, Harada M, Ohe Y, Nogami N, Takeuchi K, Shimada T, Tanaka T and Tamura T: CH5424802 (RO5424802) for patients with $A L K$-rearranged advanced non-small-cell lung cancer (AF-001JP study): A single-arm, open-label, phase 1-2 study. Lancet Oncol 14: 590598, 2013

8 Peters S, Camidge DR, Shaw AT, Gadgeel S, Ahn JS, Kim DW, Ou SI, Pérol M, Dziadziuszko R, Rosell R, Zeaiter A, Mitry E, Golding S, Balas B, Noe J, Morcos PN, Mok T and ALEX Trial Investigators: Alectinib versus crizotinib in untreated ALKpositive non-small-cell lung cancer. N Engl J Med 377: 829-838, 2017.

9 Hida T, Nokihara H, Kondo M, Kim YH, Azuma K, Seto T, Takiguchi Y, Nishio M, Yoshioka H, Imamura F, Hotta K, Watanabe S, Goto K, Satouchi M, Kozuki T, Shukuya T, Nakagawa K, Mitsudomi T, Yamamoto N, Asakawa T, Asabe R, Tanaka $\mathrm{T}$ and Tamura $\mathrm{T}$ : Alectinib versus crizotinib in patients with ALK-positive non-small-cell lung cancer (J-ALEX): An open-label, randomised phase 3 trial. Lancet 390: 29-39, 2017.

10 Gainor JF, Dardaei L, Yoda S, Friboulet L, Leshchiner I, Katayama R, Dagogo-Jack I, Gadgeel S, Schultz K, Singh M, Chin E, Parks M, Lee D, DiCecca RH, Lockerman E, Huynh T, Logan J, Ritterhouse LL, Le LP, Muniappan A, Digumarthy S, Channick C, Keyes C, Getz G, Dias-Santagata D, Heist RS, Lennerz J, Sequist LV, Benes CH, Iafrate AJ, Mino-Kenudson M, Engelman JA and Shaw AT: Molecular mechanisms of resistance to first- and second-generation ALK inhibitors in $A L K$-rearrangement-positive lung cancer. Cancer Discov 6: 1118-1133, 2016.

11 Eisenhauer EA, Therasse P, Bogaerts J, Schwartz LH, Sargent D, Ford R, Dancey J, Arbuck S, Gwyther S, Mooney M, Rubinstein L, Shankar L, Dodd L, Kaplan R, Lacombe D and Verweij J: New Response Evaluation Criteria in Solid Tumours: Revised RECIST Guideline (version 1.1). Eur J Cancer 45: 228$247,2009$.

12 Horinouchi H, Maemondo M, Hida T, Takeda M, Hotta K, Hirai F, Kim YH, Matsumoto S, Mitsudomi T, Seto T, Moizumi S, Tokushige S, Hatano B and Nishio M: Phase 2 study of ceritinib in patients with ALK+ NSCLC with prior alectinib treatment in Japan: ASEND-9. J Thorac Oncol 12: S1952-1953, 2017.
13 Katayama R, Lovly CM and Shaw AT: Therapeutic targeting of anaplastic lymphoma kinase in lung cancer: A paradigm for precision cancer medicine. Clin Cancer Res 21: 2227-2235, 2015.

14 Isozaki H, Ichihara E, Takigawa N, Ohashi K, Ochi N, Yasugi M, Ninomiya T, Yamane H, Hotta K, Sakai K, Matsumoto K, Hosokawa S, Bessho A, Sendo T, Tanimoto M and Kiura K: Non-small cell lung cancer cells acquire resistance to the ALK inhibitor alectinib by activating alternative receptor tyrosine kinases. Cancer Res 76: 1506-1516, 2016.

15 Doebele RC, Pilling AB, Aisner DL, Kutateladze TG, Le AT, Weickhardt AJ, Kondo KL, Linderman DJ, Heasley LE, Franklin WA, Varella-Garcia $M$ and Camidge DR: Mechanisms of resistance to crizotinib in patients with $A L K$ gene rearranged nonsmall cell lung cancer. Clin Cancer Res 18: 1472-1482, 2012.

16 Tanizaki J, Okamoto I, Okabe T, Sakai K, Tanaka K, Hayashi H, Kaneda H, Takezawa K, Kuwata K, Yamaguchi H, Hatashita E, Nishio K and Nakagawa K: Activation of HER family signaling as a mechanism of acquired resistance to ALK inhibitors in EML4-ALK-positive non-small cell lung cancer. Clin Cancer Res 18: 6219-6226, 2012.

17 Lin YT, Yu CJ, Yang JC and Shih JY: Anaplastic lymphoma kinase $(A L K)$ kinase domain mutation following ALK inhibitor(s) failure in advanced ALK-positive non-small-cell lung cancer: Analysis and literature review. Clin Lung Cancer 17: e77-e94, 2016.

18 Lin JJ, Riely GJ and Shaw AT: Targeting ALK: Precision medicine takes on drug resistance. Cancer Discov 7: 137-55, 2017.

19 Katayama R, Friboulet L, Koike S, Lockerman EL, Khan TM, Gainor JF, Iafrate AJ, Takeuchi K, Taiji M, Okuno Y, Fujita N, Engelman JA and Shaw AT: Two novel $A L K$ mutations mediate acquired resistance to the next-generation ALK inhibitor alectinib. Clin Cancer Res 20: 5686-5696, 2014. 